\title{
Policy and Programme Effect of COVID-19 on Economy in India
}

\author{
K. Kamala ${ }^{1}$ \\ ${ }^{1}$ Dept. of Political Science, New Govt Degree College, Serilingampally, R.R.Telangana, India \\ Correspondence: Dr. K. Kamala, Asst. Professor, Dept. of Political Science, New Govt Degree College, \\ Serilingampally, R.R.Telangana, India. E-mail: kamala.ranu@gmail.com
}

Received: October 18, 2020

doi:10.20849/ajsss.v5i4.847

Accepted: November 20, 2020

Online Published: January 5, 2021

URL: https://doi.org/10.20849/ajsss.v5i4.847

\begin{abstract}
The outbreak of COVID-19 brought social and economic life to a standstill. In this study the focus is on assessing the impact on affected sectors, such as aviation, tourism, retail, capital markets, MSMEs, and oil. International and internal mobility is restricted, and the revenues generated by travel and tourism, which contributes $9.2 \%$ of the GDP, will take a major toll on the GDP growth rate. Aviation revenues will come down by USD 1.56 billion. Oil has plummeted to 18 -year low of $\$ 22$ per barrel in March, and Foreign Portfolio Investors (FPIs) have withdrawn huge amounts from India, about USD 571.4 million. While lower oil prices will shrink the current account deficit, reverse capital flows will expand it. Rupee is continuously depreciating. MSMEs will undergo a severe cash crunch. The crisis witnessed a horrifying mass exodus of such floating population of migrants on foot, amidst countrywide lockdown. Their worries primarily were loss of job, daily ration, and absence of a social security net. India must rethink on her development paradigm and make it more inclusive. COVID 19 has also provided some unique opportunities to India. There is an opportunity to participate in global supply chains, multinationals are losing trust in China. To 'Make in India', some reforms are needed, labour reforms being one of them.
\end{abstract}

Keywords: COVID 19, economic impact, GDP growth rate, sectoral impact, COVID relief measures

\section{Introduction}

The outbreak of COVID-19 has impacted nations in an enormous way, especially the nationwide lockdowns which have brought social and economic life to a standstill. A world which forever buzzed with activities has fallen silent and all the resources have been diverted to meeting the never-experienced-before crisis. There is a multi-sectoral impact of the virus as the economic activities of nations have slowed down. What is astonishing and worth noting is an alarm bell which was rung in 2019 by the World Health Organization (WHO) about the world's inability to fight a global pandemic. A 2019 joint report from the WHO and the World Bank estimated the impact of such a pandemic at 2.2 per cent to 4.8 per cent of global GDP. That prediction seems to have come true, as we see the world getting engulfed by this crisis.

In another report entitled 'COVID-19 and the world of work: Impact and policy responses' by International Labour Organization, it was explained that the crisis has already transformed into an economic and labour market shock, impacting not only supply (production of goods and services) but also demand (consumption and investment). International Monetary Fund's (IMF) chief said that, 'World is faced with extraordinary uncertainty about the depth and duration of this crisis, and it was the worst economic fallout since the Great Depression'. The IMF estimated the external financing needs for emerging markets and developing economies in trillions of dollars. India too is groaning under the yoke of the pandemic and as per news reports in Economic Times published on 23 March 2020, the economists are pegging the cost of the COVID-19 lockdown at US\$120 billion or 4 per cent of the GDP (The Economist, 2020).

This COVID-19 pandemic affected the manufacturing and the services sector-hospitality, tours and travels, healthcare, retail, banks, hotels, real estate, education, health, IT, recreation, media and others. The economic stress has started and will grow rapidly. While lockdown and social distancing result in productivity loss on the one hand, they cause a sharp decline in demand for goods and services by the consumers in the market on the other, thus leading to a collapse in economic activity. However, lockdown and social distancing are the only cost-effective tools available to prevent the spread of COVID-19. Governments are learning by doing, as it was in the case of success of containment strategy in Bhilwara district, Rajasthan, India, the economic risks of 
closing the economy remain nonetheless. Similarly, flattering the caseload curve is critical for economy at large, but it comes with an economic cost.

\section{Material and Methods}

Research studies done earlier to assess the economic impact of epidemics have been based on simulation models. A study done by Martin Karlsson (2014) to assess the impact of 1918 Spanish flu epidemic on Swedish economy is based on the neoclassical growth model; an extension of the standard difference-in-differences (DID) estimator was employed to exploit the differing flu mortality rates across Swedish regions. The policy brief issued by the Asian Development Bank to assess the economic impact of Avian Flu pandemic on Asian economies has been done through macroeconomic simulations based on Oxford Economic Forecasting (OEF) global model, which incorporates both the demand and supply sides and adjusts to a new equilibrium after a shock (Bloom et al., 2005). The empirical estimates of the economic effects of the Severe acute respiratory syndrome (SARS) epidemic are based on a global model called the G-Cubed (Asia-Pacific) model which was proposed by Lee and McKibbin (2004). Economic effects of epidemics are measured through economic costs deriving from disease-associated medical costs or forgone incomes as a result of the disease-related morbidity and mortality. In a global economy, the economic consequences of an epidemic in one country are transferred to other countries because of the integrated supply chains and capital markets. COVID-19 pandemic is caused by novel coronavirus infection, and scientific research is going on to study the impact of this infection on the human body and to find a possible cure for the infection. There are many variables in the epidemiological calculations done for this disease which are based on assumptions such as the cause of infection, the infection rate and the ratio of asymptomatic cases to symptomatic cases. In the future, scientific research will unravel the mysteries of this disease and the disease spread. Economic projections or simulations are closely linked to epidemiological forecasting of the disease pattern. We decided not to use simulation models because of the uncertainties related to the disease. In this study, the focus is on assessing the damages caused by COVID-19 in the affected sectors, such as aviation, tourism and the retail, the overall productivity loss and the socio-economic impact of labour hours lost with an analysis of developmental policy and programme implications.

\section{Sectoral Implications of COVID-19 Pandemic in India Impact on Tourism, Aviation and Retail}

The tourism industry is the worst affected due to the COVID crisis, internationally. The World Tourism Organization (UNWTO) (2020) estimations depict a fall of 20-30 per cent in international tourist arrivals. These figures too are based on present circumstances and are likely to increase or decrease in future. Millions of people associated with industry are likely to lose their jobs. In India, the travel and tourism industry is flourishing and is contributing sizably to the economy.

The FICCI-Yes Bank report titled 'India Inbound Tourism: Unlocking the Opportunities' described India as a tourism powerhouse and the largest market in South Asia. Tourism in India accounted for 9.2 per cent of GDP and had generated US\$247.3 billion in 2018, with the creation of 26.7 million jobs. Currently, it is the 8th largest country in terms of contribution to GDP (JaganMohan, 2020). According to the report, by 2029, the sector is expected to provide employment to nearly 53 million people. Foreign Tourist Arrivals (FTAs) crossed 10 million in 2017. However, the coronavirus pandemic has restricted international mobility and the revenues generated by this sector will take a major toll on the GDP growth rate. It may bring a downfall of 0.45 per cent in the growth rate of GDP.

The aviation sector in India currently contributes US\$72 billion to India's GDP. Foreign tourist arrival has been down in the first quarter. The lockdown will have a significant impact on arrivals in the second quarter. If we estimate a conservative 25 per cent decline in the contribution of the aviation sector, it will amount to 18 billion. Railways contributed US $\$ 27.13$ billion in 2019 to GDP. A 21-day lockdown period will bring down the revenue by US $\$ 1.56$ billion.

The Indian retail industry was worth US\$790 billion in FY 2019. It accounts for over 10 per cent of the country's GDP and around 8 per cent of employment. In the past few years, online retail has seen a very rapid growth and the market projections had indicated a 30 per cent growth in online retail in 2020 (National Investment Promotion and Facilitation Agency, 2020). A month-long shutdown for retail will affect the Quarter 2 revenues. In the retail sector, the suppressed demand has a tendency to revive very fast and this will enable the sector to recover the losses once the lockdown is lifted. Online retail was operational in some parts of the country during the lockdown period and this will help in offsetting some of the losses for the industry.

\section{Impact on GDP Growth Rate}

While the COVID-19 pandemic is constantly growing and showing little signs of containment as of 15 April 
2020 , its adverse impact on economic growth of the country will probably be very serious. The UN warned that the coronavirus pandemic is expected to have a significant adverse impact on global economy, and most significantly, GDP growth of India for the present economy is projected to decline to 4.8 per cent (United Nation 2020). Similarly, the UN 'Economic and Social Survey of Asia and the Pacific (ESCAP) 2020 reported that COVID-19 would have extensive socio-economic consequences in the region with inundate activities across borders in the areas of tourism, trade and financial linkages (United Nations, 2020).

Economic Survey 2019-2020 had provided advance estimates for growth in real GDP during 2019-2020 at 5.0 per cent, as depicted in Table 1, as compared to the growth rate of 6.8 per cent in 2018-2019. The nominal GDP is estimated at ₹204,400 billion in 2019-2020 with a growth of 7.5 per cent over the provisional estimates of GDP ( ₹190,100 billion) for 2018-2019. (Economic Survey, 2020, p. 100) On 28 February 2020, the National Statistical Office announced revised estimates of GDP growth, from 8 per cent to 7.1 per cent in the first quarter, from 7 per cent to 6.2 per cent in the second quarter and from 6.6 per cent to 5.6 per cent in the third quarter. Goldman Sachs estimated the growth rate of GDP at 1.6 per cent, declining by 400 basis points because of 21-day lockdown (Goldman Sachs, 2020). In case of a quick retraction of COVID-19 pandemic across the globe by mid-May, KPMG India estimated India's GDP growth in the range of 5.3 per cent to 5.7 per cent. In second scenario where India controls the virus spread but there is a significant global recession, the growth may be between 4 per cent and 4.5 per cent. KPMG India in its report estimated India's GDP growth rate falling below 3 per cent if the virus spreads further in India and lockdown sees an extension (KPMG, 2020). Motilal Oswal research suggests that a single day of complete lockdown could shave off 14-19 basis points from annual growth (Oswal, 2020). Barclays reported the cumulative shutdown cost to be around US $\$ 120$ billion, or 4 per cent of GDP (Barclays, 2020). Mr Yashwant Sinha, former Finance Minister of India, estimated the cost of 21 -day countrywide lockdown at 1 percentage point of GDP. The global recession and uncertainties of future might make a 2 percentage point decline in growth rate (for 2020-2021) possible.

\section{Impact of COVID-19 Pandemic on Migratory Labour}

The International Labour Organization in its report describes the coronavirus pandemic as 'the worst global crisis since World War II'. About 400 million people (76.2\% of the total workforce) working in the informal economy in India are at a risk of falling deeper into poverty due to catastrophic consequences of the virus. As half of the world is in lockdown, it is going to be a loss of 195 million full-time jobs or 6.7 per cent of working hours globally. Many are in low-paid, low-skilled jobs where sudden loss of income is catastrophic (International Labour Organisation, 2020).

Seasonal migration of labour for work is a pervasive reality in rural India. A migration of millions of people happens from rural areas to industries, urban markets and farms. Major migration corridors in India are from UP and Bihar, to Punjab, Haryana, Maharashtra and Gujarat. Newer corridors from Odisha, West Bengal and North East to Karnataka and Andhra Pradesh, from Rajasthan to Gujarat, from MP to Gujarat and Maharashtra and from Tamil Nadu to Kerala are also being created. These migrant workers are employed in the construction sector (40 million), domestic work (20 million), textile (11 million), brick kiln work (10 million), transportation, mining and agriculture (IIPS, 2001). During lockdown, 92.5 per cent of labourers have lost 1 to 4 weeks of work. A survey done by Jan Sahas, of 3196 migrant workers across northern and central India, between 27 March and 29 March, reveals that 80 per cent of migrant workers feared that they will run out of food before lockdown ends on 14 April and will not get their job back thereafter (Figure 1). The survey revealed that 55 per cent of migrant workers get a daily wage between ₹ 200 and ₹ 400 , and 39 per cent of the workers get it between ₹400 and ₹600, which is below minimum wage rate. Only 4 per cent of the workers get ₹600 and above, which is close to minimum wage rate. They work in exploitative conditions, are often under debt and have little savings of their own. About 49.2 per cent of these workers in the survey said that they did not have ration and 39.4 per cent said that they had ration which would last about 2 weeks.

The survey further explains that about 99.2 per cent of these workers have Aadhaar card, 86.7 per cent have a bank account or Jan Dhan documents, 61.7 per cent have ration cards and 23.7 per cent have Below Poverty Line (BPL) cards. Although government has announced a relief package of ₹1,700 billion, many of them might find it difficult to avail the benefits. These workers expected the government to provide for monthly ration and monthly financial support (Jan Saahas Survey, 2020). The crisis witnessed a horrifying mass exodus of such floating population of migrants on foot amidst the countrywide lockdown. Their worries primarily emanating from loss of job and absence of a social safety net. Despite assurance from the government, they continued to walk back to their homes. It is a saga of inequality, poverty and social exclusion of vulnerable populations struggling to overcome this sudden crisis. 
The Supreme Court sought a status report from the Centre on the measures taken to prevent the mass exodus of migratory labourers to their villages. A sudden displacement of workers due to coronavirus will have far-reaching effects on the Indian economy. Some of these workers may not return to work in the industrial towns of Gurugram, Surat and Mumbai. They may seek employment in their marginal farms or in the nearby areas. The consequences of behaviour changes forced by lockdown will put pressure on MSMEs and farm sector, as labour will not be available soon after lockdown. If not properly addressed through policy, the social crisis created by the COVID-19 pandemic may also increase inequality, exclusion, discrimination and global unemployment in the medium and long term.

\section{Implications on Capital Markets, Global Oil Market and Its Impact on India}

Coronavirus fears have sent shock waves across global financial markets. Indian capital markets are envisaging a funds flow to Western capital markets, owing to rate cuts and fall in the stock markets the world over. As per the NSDL data, Foreign Portfolio Investors (FPIs) have withdrawn huge amounts from India—₹247.76 billion from equity markets and ₹ 140.50 billion from debt markets in a short span of 13 days, that is, from 1 to 13 of March 2020. There will be a lot of volatility in the capital markets in the next 6 months, owing to rapid flow of capital from one market to another in the world.

A historic drop in demand for oil has dropped the crude oil prices to an 18 year low of US\$22 per barrel, in March from US $\$ 65$ per barrel in January. Some estimates have pegged a saving of US\$7-8 billion for India for every US $\$ 5$ a barrel fall in crude oil prices. A fall in crude oil prices may cut India's current account deficit, which was 1.55 of GDP in 2019-2020 (Economic Survey, 2020). But the capital outflows from India may exceed the potential saving in the current account deficit. INR to USD average exchange rate has been ₹70.4 per US dollar, but it is already quoting near the psychological barrier of ₹75 per US dollar. If capital outflows from India continue, rupee (INR) may depreciate further in the coming days.

\section{Policy and Programme Implications Fiscal and Monetary Measures}

Coronavirus pandemic demands coordinated fiscal and monetary policy measures to deal with it. The fiscal measures include paying the healthcare bill raised by the pandemic. Providing for masks, gloves, testing kits, personal protection equipment, ventilators, ICU beds, quarantine wards, medicines and other equipment would mean a huge increase in healthcare spending. Public spending on healthcare in India is 1.1 per cent of GDP. It is likely to increase in the current fiscal year. The government has declared a relief package of ₹1,700 billion, it will be used to make cash transfers to the poor and vulnerable sections of the society. The sectors that are affected the most, that is, MSMEs and the farms, will be supported by another relief package which will be announced soon. Tourism and those sectors which are integrated with global supply chains will require support. Tax revenues will also drop due to recession. Fiscal receipts could drop by at least 2 per cent of GDP. All these fiscal measures will increase fiscal deficit by $1-1.5$ per cent, which is currently at 3.2 per cent, as predicted by economists.

The crisis emerging from the coronavirus spread will pull down investment and consumption demand. Conventionally, the demand side components of GDP account for 72.1 per cent consumption, out of which government consumption is barely 11.9 per cent as depicted in Table 2 . An anxiety-induced reluctance to spend is the main threat to economic growth rate. The government will have to increase the spending in order to boost demand. Support to different sectors will have to be given as a measure to boost investment demand. Repo Rate has been reduced by 75 basis points, as part of a loose monetary policy. The federal reserve had cut its interest rate by 1 percentage point and decided to keep it in the range of $0-0.25$ per cent in the USA. Monetary policy is less effective in dealing with a pandemic because the problem is not liquidity alone. The disruption of economic activity and the uncertainty of future bring down the investment sentiment. An anxiety-induced frugality among firms and investors wipes out the investment demand.

\section{Impact on Start-ups and Micro, Small and Medium Enterprises}

Micro, Small and Medium enterprises, which have created more than 90 per cent of the jobs in India, employing over 114 million people and contributing 30 per cent of the GDP (Radhika Pandey, 2020), are at the risk of having a severe cash crunch if the lockdown is extended to 8 weeks. Many of these MSMEs have loan obligations and monthly EMIs to pay. Many of them might just disappear if their cash cycle is disturbed because of the lockdown, with fixed costs dangling over them in such a situation. They need a moratorium for loan repayments. RBI has released funds to non-banking financial corporations, some of whom provide finance to MSMEs. In addition to that, movement of perishable goods is hampered and thus, these businesses stare at huge losses. India cannot have a real and sustainable growth without having a thriving MSME sector. The COVID-19 crisis will also test the resilience of start-ups in India. Start-ups have to rely on cross-border fund raising. Several 
founders are seeing their businesses grinding to a halt. Receivables are spiralling and they have to undertake painful cost-reduction measures in their ventures. Government will have to make funds available to this sector, as venture capital firms may take a little longer to come and support because of the restricted global capital flows.

\section{Economic Inequity and a Rethink on Developmental Paradigm for India}

The Oxford Committee for Famine Relief (OXFAM) report on 'Income Inequalities in India', 2019, brought forth some eye-opening findings on asymmetrical developmental paradigm in India. The report mentioned that in 2017-2018, the richest 1 per cent of the population owned 73 per cent of the wealth generated in the country. The wealth of this group increased by ₹20913 billion, which is equivalent to the total budget of the central government in the same year. Richest 1 per cent in the country hold more than four times the wealth held by 953 million (bottom $70 \%$ of the country's population). Six hundred and seventy million Indians who comprise the poorer half of the population saw 1 per cent increase in their wealth in 2017-2018. It is clear that the benefits of development have been claimed by a few people in the society. Stark income inequities in the country explain why a large part of the population which belongs to subsistence sector does not demand anything more than subsistence needs of food and shelter. An economic shock resulting from natural calamity or a pandemic pushes many others back to the subsistence sector. The COVID-19 pandemic has brought forth lopsided development in the country to the forefront. Loss of daily wages has forced a large segment of the society to struggle with hunger, unless a relief measure is provided to them.

\section{Discussion}

A micro virus has eroded wealth and corroded investor confidence, slowed-down private consumption and investment, disrupted workplaces and distorted markets. Economic Survey 2019-2020 had laid out a plan to promote exports of network products, to integrate 'assemble in India for the world' into Make in India and to create 40 million jobs by realising the aspiration of a 5 trillion economy by 2025 (Economic Survey, 2020, p. 100). The COVID-19 pandemic has forced us to rethink on these strategies. Integration with global supply chains also makes the nation susceptible to global supply shocks. The survey had mentioned, 'As no other country can match China in the abundance of its labour, we must grab the space getting vacated in labour-intensive sectors'. The COVID-19 pandemic posed a huge threat to the mainstay of global production because the mobility of Chinese migrant workers was restricted and the production activity had come to a halt. Half of the humanity at present is under lockdown, and if lockdown persists, in the rest of the world, lost sales in Chinese firms will result in layoffs, cuts in investment spending and a deep recession. A rise in demand for commodities, if the virus does not get contained, will increase prices, even when there is a global supply shock and unemployment rates are high, and that is when stagflation sets in. The Indian economy will be largely protected from these global upheavals because Indian producer, except in a few sectors, is not a participant in global supply chains.

One of the imminent reforms to be done in the country is labour reforms. Labour laws are outmoded in India, and some of these date back to the last century. India's complex labour laws have been blamed for keeping manufacturing businesses small and hindering job creation. Industry hires labour informally because of complex laws and that is responsible for low wages. The unemployment rate in India peaked in 2018, at 45 years high of 8.1 per cent (The Hindu, 2019). A rise in wages as a result of simplified labour laws will boost demand and provide inducement to invest. The COVID-19 pandemic has provided an opportunity to expedite the process of labour reforms. Financial inclusion with labour reforms will help in increasing wages and reducing unemployment.

Before the advent of modern state, social security was largely community based in India. The community (in villages and cities) used to take care of the old, poor and vulnerable. Sharing food or giving food as alms was a part of daily routine and was an important part of our culture. Many charitable works for the community were undertaken by those who had resources within the community. At the time of crisis, the state provided help, but a large part of help came from local philanthropists. After the creation of modern state, community-based social security measures were discontinued. State-sponsored social security net for all is yet to be developed in India. Social security measures are segregated. It is time to provide a social security card (with a unique identification number) to everyone in the country, along with a 100 per cent financial inclusion. Availability of advanced digital technology can easily make this possible in India. Massive exodus of migrant labourers, news of some of them dying as a result of walking miles in the scorching sun, and many remaining hungry for days are some of the most disturbing images of lockdown. Duplication of relief efforts in the absence of a formal social security net and having no way to reach the last mile where a part of the population remains left out are some of the 
realities that have been brought forward by the pandemic. It is time to create a robust state-sponsored social security net for every citizen of the country.

\section{Conclusion}

The spiralling and pervasive COVID-19 pandemic has distorted the world's thriving economy in unpredictable and ambiguous terms. But it significantly indicated that the current downturn seems primarily different from recessions of the past which had jolted the country's economic order. Whereas the nations, conglomerates, corporations and multinationals continue to understand the magnitude of the pandemic, it is undoubtedly the need of the hour to prepare for a future that is sustainable, structurally more viable for living and working.

While the unprecedented situation has caused a great damage to the economy, especially during periods of lockdown, the nation will have to work its way through it, by introduction of fiscal measures. As the national government envisions, protection of both lives and livelihood is required. The economic activity must begin gradually after screening of the labour force. Strict preventive measures should be implemented by the industry in order to safeguard the health of the workers. While policy and reforms should be doled out by the government adequately to salvage the economy, the industry, civil societies and communities have an equal role in maintaining the equilibrium. The norms of social distancing, avoiding or cancelling gatherings, and use of masks and sanitisers should be the way of life till we are able to eradicate the virus. During this time, the economy is juxtaposed with social behaviour of humankind, so the responsibility of bringing back economic action is not of government alone.

The risk of a global recession due to COVID-19 in 2020 and 2021 would be extremely high, as it has been observed globally that the shutdown of all economic activities - production, consumption and trade - to control the spread of COVID-19 is imminent. The nature of shutdown is unique in case of COVID-19 due to a supply shock, a demand shock and a market shock. The recovery in economy depends on the timings and magnitude of government support as well as the level of corporate debt and how the companies and markets cope with lower demand. Government assistance to those most in need (largely constituted of unorganised sector, migrants and marginalised communities) is a critical measure to save many lives.

However, every crisis brings about a unique opportunity to rethink on the path undertaken for the development of a human being, community and society. The COVID-19 pandemic has a clear message for the Indian economy to adopt sustainable developmental models, which are based on self-reliance, inclusive frameworks and are environment friendly.

\section{References}

Barclays. (2020). How will India lockdown play out for economy \& markets: 4 scenarios. Economic Times. Retrieved from https://economictimes.indiatimes.com/markets/stocks/news/how-will-india-lockdown-play-out-for-econom y-markets-4-scenarios/articleshow/74804087.cms

Bloom, E., Wit, V. D., \& Jose, M. J.-S. (2005). Potential economic impact of an Avian Flu Pandemic on Asia. Asian Development Bank. Retrieved from https://www.think-asia.org/handle/11540/2165

Economic Survey. (2020). Chapter 5. Government of India.

Economic Survey. (2020). Key indicators. Government of India.

IIPS. (2001). Major net migration flows. Indian Institute of Population Sciences.

International Labour Organisation. (2020). COVID-19 and the world of work, impact and policy responses. ILO.

JaganMohan, M. (2020). Travel and tourism industry in India, statistics and facts. Retrieved from https://www.statista.com/topics/2076/travel-and-tourism-industry-in-india/

Jan Saahas Survey. (2020). Lockdown is only the beginning of misery for India's migrant labourers. Quartz.com. Retrieved from https://qz.com/india/1833814/coronavirus-lockdown-hits-india-migrant-workers-pay-food-supply/

KPMG. (2020). Coronavirus: India's GDP growth may fall below 3\% if lockdown extends, says KPMG report. Business Today. Retrieved from https://www.businesstoday.in/current/economy-politics/coronavirus-india-gdp-growth-may-fall-below-3-if-1 ockdown-extends-says-kpmg-report/story/400135.html

Lee, J.-W., \& McKibbin, J. W. (2004). Estimating the global economic costs of SARS. In Knobler, S., Mahmoud, A., Lemon, S., Mack, A., Sivitz, L., \& Oberholtzer, K. (Eds.), Learning from SARS: Preparing for the next 
disease outbreak. Institute of Medicine (US) Forum on Microbial Threats. Retrieved from https://www.ncbi.nlm.nih.gov/books/NBK92473/

Martin Karlsson, T. N. (2014, July). The impact of the 1918 Spanish flu epidemic on economic performance in Sweden: An investigation into the consequences of an extraordinary mortality shock. Journal of Health Economics. Retrieved from https://www.sciencedirect.com/science/article/pii/S0167629614000344

National Investment Promotion and Facilitation Agency. (2020). Invest India. Retrieved from https://www.investindia.gov.in/sector/retail-e-commerce

Oswal, M. (2020, March 26). With 75\% economy under lockdown, analysts see sharp fall in GDP. Business Standard. Retrieved from https://www.business-standard.com/article/economy-policy/with-75-economy-under-lockdown-analysts-see -sharp-fall-in-gdp-120032600231_1.html

Radhika Pandey, A. P. (2020). Covid-19 and MSMEs: The 'identification' problem. Ideas for India for More Evidence Based Policy. Retrieved from https://www.ideasforindia.in/topics/macroeconomics/covid-19-and-the-msme-sector-the-identification-probl em.html

Sonal Verma, A. N. (2020). COVID-19's impact on the world economy. Nomura.

The Economist. (2020, February). Apple's Chinese troubles. Retrieved from https://www.economist.com/business/2020/02/20/apples-chinese-troubles

The Economist. (2020, February 15). The new coronavirus could have a lasting impact on global supply chains. Retrieved from https://www.economist.com/international/2020/02/15/the-new-coronavirus-could-have-a-lasting-impact-onglobal-supply-chains?cid1=cust/ednew/n/bl/n/2020/02/29n/owned/n/n/nwl/n/n/AP/415278/n

The Hindu. (2019). Unemployment rate at 45 -year high, confirms Labour Ministry data.

United Nations. (2020). Economic and social survey of Asia and the Pacific. Economic and Social Commission for Asia and the Pacific Decade of Action (ESCAP).

\section{Copyrights}

Copyright for this article is retained by the author(s), with first publication rights granted to the journal.

This is an open-access article distributed under the terms and conditions of the Creative Commons Attribution license (http://creativecommons.org/licenses/by/4.0/). 